ORIGINAL ARTICLE

\title{
Evaluation of contamination of wooden residue sources by human activities
}

\author{
Avaliação da contaminação de fontes de resíduos de madeira por \\ atividades humanas \\ Carlos Rogério Andrade ${ }^{1}$ (1) , Ananias Francisco Dias Júnior ${ }^{2}$ (), José Otávio Brito ${ }^{3}$ (), \\ Artur Queiroz Lana ${ }^{3}$ (1) , José Benedito Guimarães Junior ${ }^{4}$ (i), Douglas Lamounier Faria ${ }^{4}$ (1) \\ ${ }^{1}$ Universidade Federal de Jataí - UFJ, Jataí, GO, Brasil \\ ${ }^{2}$ Universidade Federal do Espírito Santo - UFES, Jerônimo Monteiro, ES, Brasil \\ ${ }^{3}$ Universidade Federal de São Paulo - USP, Piracicaba, SP, Brasil \\ ${ }^{4}$ Universidade Federal de Lavras - UFLA, Lavras, MG, Brasil
}

How to cite: Andrade, C. R., Dias Júnior, A. F., Brito, J. O., Lana, A. Q., Guimarães Junior, J. B., \& Faria, D. L. (2020). Evaluation of contamination of the wood residues sources by human activities. Scientia Forestalis, 48(128), e3161. https://doi.org/10.18671/scifor.v48n128.05

\begin{abstract}
This research work it is a case study that aimed to survey the main contaminants of urban wooden waste. The wood wastes were analyzed according to Brazilian standards and assays from literature. The woodchips were rated as Class II B - inert, according to the health and environmental recommendations of the Brazilian Association of Technical Standards (ABNT). The contamination with nails, screws, hinges and plastics was less than $1 \%$ of the dry mass of the waste. The contamination rate per mineral ranges from $10.7 \%$ for medium-density fiberboard (MDF) waste, to $25 \%$ for particleboard. Among the batch of analyzed wastes there was no trace of wood treated with CCA or CCB. Hence, some new quantitative indicators were obtained for contamination of wood wastes coming from urban areas, assisting in the choice of their use or in the final destination.
\end{abstract}

Keywords: Wood contaminant; Urban wood waste; Treated timber.

\section{Resumo}

Este trabalho é um estudo de caso que objetivou levantar os principais contaminantes de resíduos urbanos de madeira. Os resíduos de madeira foram analisados segundo padrões brasileiros e ensaios da literatura. Os cavacos de madeira foram classificados como Classe II B - inerte, de acordo com as recomendações de saúde e ambientais da Associação Brasileira de Normas Técnicas (ABNT). A contaminação com pregos, parafusos, dobradiças e plásticos foi inferior a $1 \%$ da massa seca do resíduo. A taxa de contaminação por minerais variou de $10,7 \%$ para resíduos de painéis de fibras de média densidade (MDF), até 25,0\% para painéis de partículas. Entre os lotes de resíduos analisados não foram observados vestígios de madeira tratada com CCA ou com CCB. Assim, foram obtidos novos indicadores quantitativos, para avaliar a contaminação de resíduos de madeira provenientes da área urbana, auxiliando na escolha do uso ou no destino final de tais resíduos.

Palavras-chave: Contaminante de madeira; Resíduos urbanos de madeira; Madeira tratada.

\section{INTRODUCTION}

The use of the biomass wastes as by-products and no more as residues tend to be an alternative to generate revenues and reduce environmental impacts, either in the industry, or more recently, in the public sector. Brazil opened a new field of opportunities, since approval

Financial support: None.

Conflict of interest: Nothing to declare.

Corresponding author: douglas.lamounier@yahoo.com

Received: 10 October 2018.

Accepted: 16 October 2019.

Editor: Francides Gomes da Silva Júnior.

(c) This is an Open Access article distributed under the terms of the Creative Commons Attribution License, which permits unrestricted use, distribution, and reproduction in any medium, provided the original work is properly cited. 
of the Federal Law 12.305 (Brasil, 2010) that established the National Policy on Solid Waste. Those materials that have been discarded in landfill sites and derelict land now might be useful as an energy source.

Among the countless materials discarded in an urban environment are papers, plastics, metals, glasses; and one that can be emphasized is wooden waste, either from enterprises, government offices or population. This wooden material differs from others mainly by its renewable nature and its energetic potential.

Joshi et al. (2015) referred to the term "urban wood wastes" as wooden pallets and shipping containers, construction and demolition wood, and woods that are usually contained in other urban solid wastes. According to Andrade et al. (2017), the most common features of the wood residues are the low moisture content, typically from 7 to $15 \%$, reflecting the hygroscopic moisture content of the region, and the high probability of containing other materials than wood, such as additives, metals or adhesives (U.S. Environmental Protection Agency, 2010). Furthermore, Bouslamti et al. (2012) reported the possibility of some wood to be contaminated by hazardous materials such as preservatives and heavy metals.

Wooden wastes also have been contaminated by concrete, mortar, ferrous and nonferrous metals (Brasil, 2009), soil, plaster, asbestos, paper, cardboard, wallpapers, waxes, oils, paints, varnishes, glues, adhesives, fire retardants and water (Remade Scotland, 2004). The estimation of the degree of contamination of these residues is crucial when it is destined for energy purposes. In addition, the growing demand for renewable energy sources corroborates the characterization studies of this biomass (Khudyakova et al., 2017).

The leftovers of cement and mortar adhered to the wood usually present high mineral content, coming from the civil construction sector, increasing the wear of cutting tools (Souza et al., 2009). This high level of minerals also affects the reduction of the calorific power (Brand, 2010) by increasing the amount of ashes in the combustion process (Krook et al., 2004; Brand, 2010) and in corrosion problems in metallic equipments (Brand, 2010). Nails, screws and hinges can also damage tools and machines and must previously be removed.

Other contaminants than those mentioned (mechanically removable), are those chemically linked to the wood structure, e.g. some heavy metals (Nzihou \& Stanmore, 2013). These chemical contaminations come from the use of chemical solutions for surface finishing and industrial wood preservatives, such as arsenic, chromium, copper, zinc, mercury and lead, which were widely used throughout the $20^{\text {th }}$ century (Nilsson \& Jermer, 1999). Atkins \& Donovan (1996) also reported the presence of aluminum, titanium and manganese in the urban wooden waste.

Among the currently used industrial wood preservatives, Vidal et al. (2015) mentioned the chromated copper arsenate (CCA), the chromated copper borate (CCB) and to a lesser degree the creosote. CCA is the most used preservative in the world; it is commonly used for outdoor structures, such as telegraph poles, decking and fencing, landscaping and building structures, playground equipment, and marine structures (Liu et al., 2019).

Many specialists reported that treated wooden residues are the most important sources of pollution. Frick et al. (2019) highlighted the attention to the potentially negative impact of the CCA on the environment and on health related to its concentration. For Jones et al. (2019), this type of treated wood can be found in many recycling plants and might cause an important contamination. Koyano et al. (2019) warned of the difficulties to identify those treated woods in the waste stream, reinforcing the importance of identification and using effective screening methods.

The aim of this work was to identify the main contaminants in the urban wooden waste, in a case study of a waste recycling plant. 


\section{MATERIALS AND METHODS}

\section{Material and sampling}

The collection site was a construction building waste recycling plant, receiving additionally wood from other sectors collected by the waste dumping services of the town of Piracicaba, SP/Brazil.

The sampling was done according to the Brazilian standard NBR 10007 (Associação Brasileira de Normas Técnicas, 2004c). 240 samples of construction solid wood waste and 240 of panel waste were collected. Figure 1 shows the waste pile of sampling.

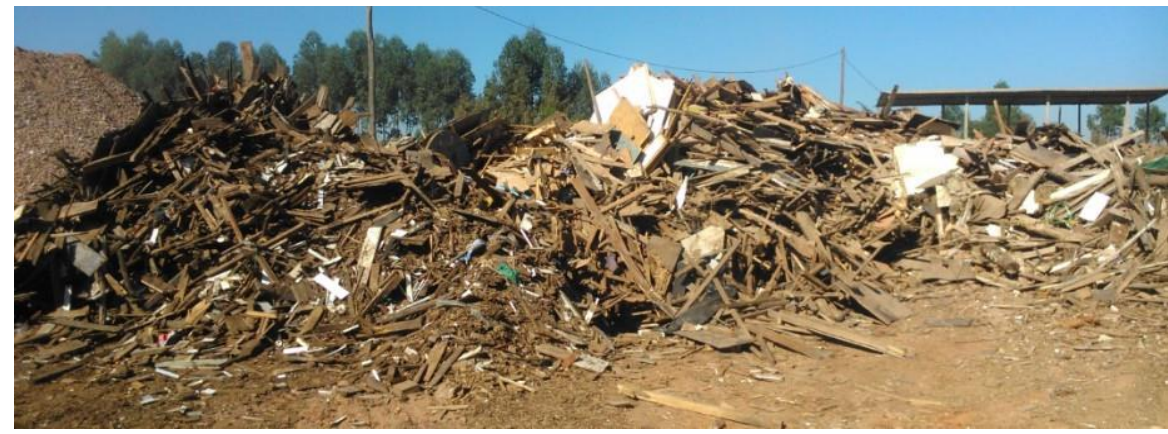

Figure 1. Sampling location.

\section{Classification of the potential risks to the environment and the human health}

To conduct the analysis, a representative sample of solid wooden waste of $5 \mathrm{~kg}$ and $5 \mathrm{~kg}$ of panels was used. The classification of the solid residues was conducted according to the methods described in the Brazilian NBR 10004 (Associação Brasileira de Normas Técnicas, 2004d), with regards to the process or activity that gave origin to them, of its components and features, with listings of waste and substances whose impact on health and the environment is known.

The reagents used for this respective analysis were: Distilled, deionized and organic free water; Hydrochloric acid (HCL) p.a., 1.0N .; Nitric acid (HNO3) p.a., 1.0 N.; Sodium hydroxide $(\mathrm{NaOH})$ p.a., $1.0 \mathrm{~N}$.; Glacial acetic acid (HOAc) p.a. Using visual inspection, the presence of metallic and non-metallic materials that were adhered to the surface of the samples was verified. The removal of these materials was done manually using hammer and pliers.

The procedures for analysis of the leached extract followed the NBR 10005 (Associação Brasileira de Normas Técnicas, 2004a), which says: class I - Hazardous; and class II - nonHazardous; as indicative of its potential polluter. The mixture consisted of a dry sample mass of $100 \mathrm{~g}$ and mixed with $2000 \mathrm{~mL}$ of the extraction solution. This mixture was kept under stirring for $18(+/-2)$ hours at $25^{\circ} \mathrm{C}$. Thereafter the leached compound was extracted by vacuum using a filter with a porosity between 0.6 to 0.8 micrometers prior to chemical analysis.

The solubility test was done according to the NBR 10006 standard (Associação Brasileira de Normas Técnicas, 2004b), which aims to rank in class II A - not Inert and class II B - Inert, as indicative of the pollution potential. The test was performed using a $250 \mathrm{~g}$ (dry base) sample of the residue in a $1500 \mathrm{~mL}$ vial and mixed with $1000 \mathrm{~mL}$ of distilled water, then the solution was filtered and analysis of the solubilized extract was performed using an atomic absorption spectrophotometer. 


\section{Characterization of mechanically removable contaminants}

\section{Metallic and non-metallic objects}

Aiming to identify and to quantify the presence of external contaminants adhering to the wood, like nails, screws, hinges and plastics, 480 samples were collected. The extracted contaminants were weighed with a sensitivity of $0.001 \mathrm{~g}$ and the results expressed in percentage of contaminants relative to the weight of the dry sample.

\section{Mineral contaminants}

The ratio of adhered mineral contaminants was determined according to the ashes content of the samples as described by the Brazilian standard NBR 8112 (Associação Brasileira de Normas Técnicas, 1986), by completely burning the material at $700{ }^{\circ} \mathrm{C}$ in muffle, after which the remaining is ash.

The protocol described by Brito \& Ceribelli (2012) was adapted to ascertain the mineral contaminant content. For each of the six residues types a composite sample was made, of which 10 grams of wood were used and sieved on a 20 mesh $(0.841 \mathrm{~mm})$ and retained on a 40 mesh $(0.420 \mathrm{~mm})$. The samples were placed in a beaker of $250 \mathrm{~mL}$, previously filled with 200 $\mathrm{mL}$ of distilled water. The suspension was stirred for a minute and left to rest for two minutes. In a next step, the supernatant material in solution was collected and dried up to constant weight. The ashes free from external contaminants were obtained according to the standard NBR 8112 (Associação Brasileira de Normas Técnicas, 1986). All procedures were done in three replications.

The contamination rate was determined using the Equation 1.

$$
\text { Txcont }=\frac{T C z t-T C z m}{T C z t} \times 100
$$

in which: Txcont $=$ contamination rate $(\%)$. TCzt $=$ total ashes content $($ wood ash + contaminant ashes) (\%). TCzm = material ash content (free of external contaminant) (\%).

\section{Identification of treated wood}

The identification test of treated wood was applied for solid wood, as far as the industry does not use treated wood as raw material for panels. The samples were submitted to colorimetric test with the chemical reagent Cromazurol $S \circledR$, which visually accuses the presence of CCA or CCB and especially of $\mathrm{Cu}$, since it detects the presence of $\mathrm{Cu}$ very accurately. Since natural wood does not contain high levels of $\mathrm{Cu}$, a positive stain result implies that the wood has been treated with $\mathrm{Cu}$.

The positively tested samples were subsequently submitted to penetration and retention tests, according to NBR 6232 (Associação Brasileira de Normas Técnicas, 2013). The penetration test was performed by colorimetric reactions using the chemical reagent Cromazurol $S \circledR$, which indicates the presence of CCA or CCB in the samples. Due to the presence of copper in the detector, a reaction occurs between the chromium of the substance chromoazurol $\mathrm{S} \circledast$ and the copper of preservatives $C C A$ and $C C B$, causing the wood to turn a dark blue color. The retention test was performed using a 30 mesh $(0.595 \mathrm{~mm})$ milled sample and analyzed by an X-ray spectrometer.

\section{Statistical analysis}

The data analysis of the variance (ANOVA) used a completely randomized design with three replicates per waste treatment. The Turkey test was applied to compare multiple means. All analyses were performed to $95 \%$ of confidence using the Minitab16.1® software and the Action Stat add on Microsoft Excel. 


\section{RESULTS AND DISCUSSION}

The results by kind of material, dry mass and its percentage and moisture content are shown in Table 1.

Table 1. Number of collected samples, dry mass and waste moisture content.

\begin{tabular}{|c|c|c|c|c|c|}
\hline Residue & $\mathbf{n}$ & DM (g) & Min. $H(\%)$ & Max. H (\%) & Mean H (\%) \\
\hline Solid Wood & 240 & 68,846. [56] & 1.96 & 37.39 & $12.26(34.07)$ \\
\hline Plywood & 92 & $28,541.6[23]$ & 4.64 & 32.50 & $12.73(34.32)$ \\
\hline Chipboard & 23 & $5,324.3[4]$ & 8.73 & 31.45 & 13.93 (31.16) \\
\hline MDF & 76 & $12,487.8[10]$ & 9.13 & 37.51 & $15.00(28.86)$ \\
\hline OSB & 20 & $3,989.3[3]$ & 6.08 & 24.03 & 11.01 (40.01) \\
\hline Hardboard & 29 & $4,524.9[4]$ & 6.27 & 12.83 & $10.24(42.85)$ \\
\hline Total & 480 & $123,714.6[100]$ & - & - & 12.69 (33.87) \\
\hline
\end{tabular}

Wherein: MDF: Medium Density Fiberboard. OSB: Oriented Strand Board. N: number of samples. DM: dry mass. Min. $\mathrm{H}$ : minimum moisture content basis. Max. H.: maximum moisture content basis. Mean $\mathrm{H}$. Mean of moisture content basis. The values between [ ] represent the percentage of dry mass of each residue relative to the total collected. Values between () are the coefficient of variation (\%).

Table 1 shows that $56 \%$ of the samples were from solid wood and $44 \%$ from panels. Within the panel category, plywood was the largest ratio with $23 \%$. This is possibly due to the fact that these materials were mainly used in the construction sector, which is a great source of waste of the recycling unit - where the sample came from in this research.

The average moisture content in all 480 samples was $12.69 \%$. This value is within the range reported for moisture wooden waste of urban origin, ranging from 7 to $20 \%$ (Atkins \& Donovan, 1996). These results are similar to those reported by Farage et al. (2013), in researching wood waste from a center of furniture production, where the moisture content observed was $17.8 \%$ for solid wood, $10.3 \%$ for chipboard and $9.8 \%$ for MDF.

The average moisture contents obtained in this study are close to the mean of equilibrium moisture of the town of collection (Piracicaba-SP/Brazil); around 12.9\% (Jankowsky \& Galina, 2013). Such a value is relatively low and even desirable according Brand (2010), because the lower the moisture content the higher is the energy efficiency, since the material does not require pre-drying.

Remade Scotland (2004) reported the interesting fact that moisture can be considered a contaminant for some end-users, as for wood fuel production, where an additional process could be necessary to remove the moisture excess.

\section{Classification of the potential risks to the environment and human health}

Results of the methods and procedures described in NBR 10004 (Associação Brasileira de Normas Técnicas, 2004d).

Physical Characteristics: moisture 3.42\%, pH (solution1:1) 5.77; Cyanide and Sulfide $<1.0$ $\mathrm{mg} . \mathrm{kg}^{-1}$; Phenol $<3.0 \mathrm{mg} \cdot \mathrm{kg}^{-1}$; Flash point $>60^{\circ} \mathrm{C}$.

\section{Leaching compound analysis.}

In the analysis of chemical leached components Barium and Fluoride were detected, with concentrations of $0.010 \mathrm{mg} \cdot \mathrm{L}^{-1}$ and $1.80 \mathrm{mg} \cdot \mathrm{L}^{-1}$, respectively. Both parameters were lower than the maximum allowed by the standard NBR 10004 (Associação Brasileira de Normas Técnicas, 2004d), that is 70 mg. L $^{-1}$ and 150 mg. L $^{-1}$, respectively. Arsenic, Cadmium, Lead, Total Chrome, Mercury, Silver and Selenium contents were lower than the detection limit values reported by the standard.

The presence of pesticides was also analyzed (Aldrin + Dieldrin; Chlordane; DDT; 2,4-D; Endrin; Heptachlor and Epoxy; lindane; methoxychlor; pentachlorophenol; toxaphene; 2,4,5- 
T; 2,4,5-TP) and other compounds (Benzene; Benzo (a) pyrene; Vinyl chloride; Chlorobenzene; chloroform; Total Cresol; o-Cresol; m-Cresol; p-Cresol; 1,4-Dichlorobenzene; 1,2Dichloroethane; 1,1-Dichloroethylene; 2,4-dinitrotoluene; hexachlorobenzene; hexachlorobutadiene; hexachloroethane; methyl ethyl ketone; nitrobenzene; pyridine; Carbon tetrachloride; tetrachlorethylene; Trichloroethylene; 2,4,5-Trichlorophenol; 2,4,6Trichlorophenol). However, the results for all these compounds were lower than the detection limit values set by the standard NBR 10004 (Associação Brasileira de Normas Técnicas, 2004d).

\section{Solubilization analysis:}

The solubilization extract was obtained according to the guidelines of the NBR 10006 (Associação Brasileira de Normas Técnicas, 2004b) (Waste Dissolving).

In the analysis of dissolved extract were detected: Aluminum (0.03 mg. $\left.\mathrm{L}^{-1}.\right)$, Chlorides (11.3 mg. $\left.\mathrm{L}^{-1}.\right)$, Iron (0.040 mg. $\left.\mathrm{L}^{-1}.\right)$, Fluoride $\left(0.13 \mathrm{mg} . \mathrm{L}^{-1}.\right)$, Manganese $\left(0.026 \mathrm{mg} . \mathrm{L}^{-1}.\right)$, Sodium (6.8 mg. $\left.\mathrm{L}^{-1}.\right)$, Sulphates $\left(11.2 \mathrm{mg} . \mathrm{L}^{-1}\right.$.) and Zinc $\left(0.20 \mathrm{mg} . \mathrm{L}^{-1}.\right)$, all of these parameters were lower than the maximum allowed by the standard NBR 10004 (Associação Brasileira de Normas Técnicas, 2004d).

It also showed low detection limits of the following compounds: Arsenic, Barium, Cadmium, Lead, Cyanides, Copper, Total Chromium, Mercury, Nitrate (as N), Silver, Selenium Surfactants, Phenols Total, and pesticides: Aldrin + Dieldrin, Chlorodane, 2,4-D, DDT, Endrin, Lindane, Methoxychlor, Toxaphene, Heptachlor and its epoxy, Hexachlorobenzene, 2,4,5-T, 2,4,5-TP.

From the analysis made in the leachate extract and solubilized extract, none of the parameters exceeded the limits stipulated by the Brazilian NBR 10004 standard. Thus, according to the Norm, wooden waste can be classified as Class II B - Inert, allowing the conclusion that, for the wooden wastes that were analyzed in this research, no chemicals were detected in its composition in sufficient concentration to cause risks to health and the environment, which in turn gives subsidy to new areas of research aimed at using the residues for energy.

\section{Metallic and non-metallic objects:}

The results for the different types of solid contaminants adhering to wood residues are shown in Figure 2.

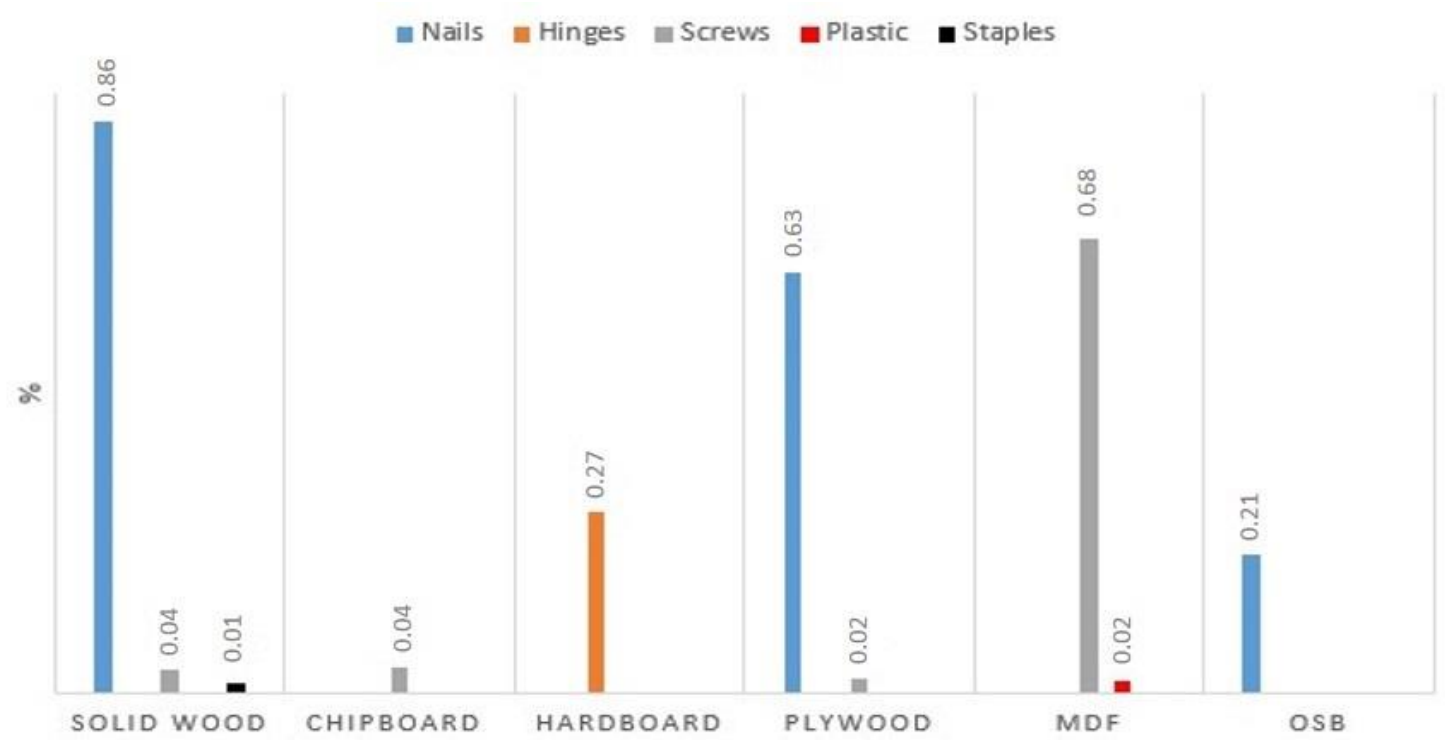

Figure 2. Distribution of mechanically removable contaminants in relation to dry matter percentage of wood. 
Solid wood, plywood and OSBwastes present the largest nail percentages, with respectively, $0.86 \%, 0.63 \%$ and $0.21 \%$. The widespread use of nails, employed in fixing planks, scaffolding, shoring and box manufacturing, among others, might explain why it is the most common contaminant in solid wood waste and plywood.

Even though the percentage of nails is relatively low, it remains a nuisance for those who work with these materials. Indeed, the decontamination of the wood from these objects requires energy expenditure, whether by mechanical or magnetic action and consequently involves costs. On the other hand, these ferrous contaminants can readily be sold for the recyclable materials market.

Screws represented $0.68 \%$ of the mass of MDF waste, i.e., in a $12 \mathrm{~kg}$ waste $84.9 \mathrm{~g}$ of screws was found. In general, discarded old furniture had the highest rate of screws in MDF waste.

The third most significant contaminant was the hinges, only found on hardboard waste. Plastic contaminants and staples were also detected, however, in a very small amount.

Regarding the quantity of externally adhered contaminants, $12.38 \mathrm{~g}$ of hinges were found in hard plate panels; $9.38 \mathrm{~g}$ of staples in solid wood residues; $118.49 \mathrm{~g}$ of screws from MDF, chipboard, plywood and solid wood panels; $2.44 \mathrm{~g}$ of plastic obtained from MDF and solid wood panels and $777.2 \mathrm{~g}$ of nails that were adhered to plywood, OSB and solid wood panels.

It is observed that the volume found for the different types of external contaminants was relatively low. Nevertheless, a suggestion for those cases where there are large quantities of these contaminants adhered to the wooden wastes would be to remove them and send them for recycling, with a possibility to generate some economic return from it and at the same time to mitigate possible environmental damages to these associated materials.

\section{Mineral contaminants}

The average values for the total ashes content, wood ashes, contaminant ashes and external contamination ratios are shown in Table 2.

Table 2. Total ashes content, wood ashes, contaminant ashes and external contamination rate.

\begin{tabular}{|c|c|c|c|c|c|c|c|c|c|c|c|c|}
\hline \multirow{3}{*}{$\begin{array}{r}\text { Waste } \\
\text { Massive Wood }\end{array}$} & \multicolumn{12}{|c|}{ Average values (\%) } \\
\hline & \multicolumn{3}{|c|}{ TCzt } & \multicolumn{3}{|c|}{ TCzm } & \multicolumn{3}{|c|}{ TCzcont } & \multicolumn{3}{|c|}{ Txcont } \\
\hline & 0.89 & c & $(0.05)$ & 0.77 & c & $(0.05)$ & 0.12 & b & $(0.01)$ & 14.3 & $a b$ & $(1.25)$ \\
\hline Plywood & 2.09 & $a$ & $(0.23)$ & 1.61 & a & $(0.15)$ & 0.49 & $a$ & $(0.08)$ & 22.96 & $a b$ & $(1.26)$ \\
\hline Chipboard & 0.96 & c & $(0.06)$ & 0.72 & c & $(0.04)$ & 0.24 & $a b$ & $(0.03)$ & 25.1 & a & (1.73) \\
\hline MDF & 1.77 & $a b$ & $(0.19)$ & 1.58 & a & $(0.13)$ & 0.19 & b & $(0.07)$ & 10.12 & $\mathrm{~b}$ & (3.10) \\
\hline OSB & 1.20 & $\mathrm{bc}$ & $(0.05)$ & 1.06 & $\mathrm{bc}$ & $(0.04)$ & 0.14 & $b$ & $(0.02)$ & 11.84 & $a b$ & $(1.27)$ \\
\hline Hardboard Waste & 1.76 & $a b$ & $(0.03)$ & 1.49 & $a b$ & $(0.12)$ & 0.26 & $a b$ & $(0.10)$ & 15.46 & $a b$ & (5.56) \\
\hline
\end{tabular}

TCzt: total ashes content. TCzm: ashes content of wood free of external contaminant. TCzcont: Ashes content of wood with external contaminant. Txcont: Rate of external contamination. Values between brackets () are the Standard Error.

Table 2 shows that the major mineral contamination is associated with plywood (22.9\%) and chipboard $(25 \%)$, which means that almost a quarter of all the minerals present in these residues come from external sources. These values are similar to those obtained by Brand (2010), studying various types of wood waste which resulted in the following ashes content: pine chip from sawmill 1.87\%; pine sawdust 1.13\%. Pincelli (2011) analyzed residues from pine and eucalyptus forest harvesting and found ash contents of $0.53 \%$ and $0.98 \%$ respectively. Lopes (2012) obtained ash content of $1.1 \%$ in a mixture of pine and eucalyptus waste and 
$1.44 \%$ for mixture of waste panels, old furniture and construction wood. Zau et al. (2014) studied Amazonian wood waste and obtained an average ash content of 1.72\%.

According to Brand (2010), the ash content, either natural or contaminated, estimated by in immediate analysis is crucial because of two reasons: the ash is not burnt, remaining at the processing site and it may need disposal; it can be abrasive and corroding metal equipment.

\section{Detection of treated wood}

The detection of treated wood in the solid wood samples was performed by colorimetric test with the Cromazurol $S \bowtie$ reagent.

From the examined samples, only 25 changed their color, from a natural color for staining to a blueish to purple. Figure 3 shows the samples before and after the colorimetric test, in which a sample was purposely inserted to indicate the comparative effect.
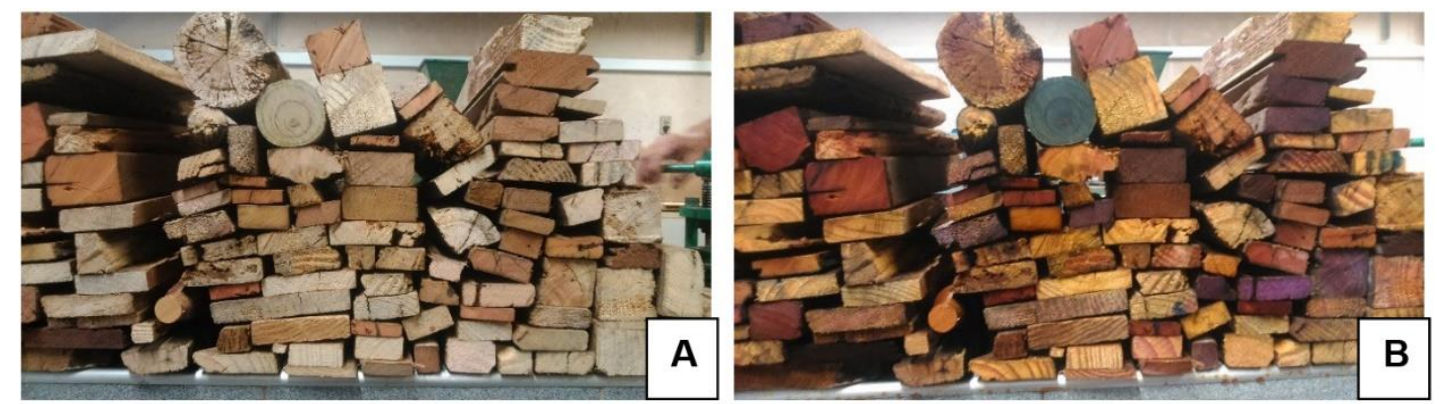

Figure 3. Samples submitted to a colorimetric test. (A) before the test and (B) after the test. The sample that presented a positive result to the colorimetric test was inserted to allow the comparative effect.

The color changing induced by the chemical reagent, gives a clue if the samples should be submitted to the penetration and retention tests according to NBR 6232 (Associação Brasileira de Normas Técnicas, 2013). The penetration and retention test was performed on the 25 samples and the presence of CCA and CCB was not observed.

The fact that the samples had presented a color change by colorimetric assay does not necessarily mean the presence of preservative solutions. In this case, it most likely occurred due to a reaction between the extractable wood components with the Cromazurol molecule. It may also be linked to the presence of iron hydroxide and zinc chloride; corrosive products which are usually present in the waste samples. Nevertheless false positives cases to other elements, less likely in the sample sites, might exist; such as cobalt, tin, nickel, tributyl tin oxide (TBTO) and sodium chloride.

\section{CONCLUSIONS}

According to NBR 10004 (Associação Brasileira de Normas Técnicas, 2004d) the wood analyzed in this research work were classified as Class II B - Inert. Contamination by nails, screws, plastics and hinges occurred in low percentages in comparison with the dry mass of wastes. The contamination rate by mineral was evaluated for all residues, and the highest content was obtained for agglomerates and plywood, with respectively 25 and $22.9 \%$. There was no presence of treated wood with CCA or CCB in the specimens evaluated.

\section{REFERENCES}

Andrade, C. R., Dias Júnior, A. F., Brito, J. O., Protásio, T. P., Trugilho, P. F., \& Melo, I. C. N. A. (2017). Waste wood of urban origin for energy use. Revista Árvore, 41(2), 1-8. http://dx.doi.org/10.1590/180690882017000200008.

Associação Brasileira de Normas Técnicas - ABNT. (1986). NBR 8112: immediate chemical analysis of charcoal (5 p.). Rio de Janeiro: ABNT. 
Associação Brasileira de Normas Técnicas - ABNT. (2004a). NBR 10005: procedure for obtention leaching extract of solid wastes (20 p.). Rio de Janeiro: ABNT.

Associação Brasileira de Normas Técnicas - ABNT. (2004b). NBR 10006: procedure for obtention of solubilized extraction of solid wastes (7 p.). Rio de Janeiro: ABNT.

Associação Brasileira de Normas Técnicas - ABNT. (2004c). NBR 10007: sampling of solid waste (2. ed., 21 p.). Rio de Janeiro: ABNT.

Associação Brasileira de Normas Técnicas - ABNT. (2004d). NBR 10004: solidwaste - classification (71 p.). Rio de Janeiro: ABNT.

Associação Brasileira de Normas Técnicas - ABNT. (2013). NBR 6232: penetration and retention of preservatives in pressure treated timber (1. ed., 20 p.). Rio de Janeiro: ABNT.

Atkins, R. S., \& Donovan, C. T. (1996). Wood products in the waste stream: characterization and combustion emissions (Vol. 1). Washington: United States Environmental Protection Agency.

Bouslamti, A., Irle, M. A., C, B., Salvador, V., Bondu, M., Hulo, S., \& Caron, B. (2012). Why simulate a sample of recycled wood? Maderas. Ciencia y Tecnología, 14(2), 145-153. http://dx.doi.org/10.4067/S0718-221X2012000200002.

Brand, M. A. (2010). Forest biomass energy (114 p.). Rio de Janeiro: Interciência.

Brasil. Ministério do Meio Ambiente - MMA. (2009). Use of forest residues and byproducts, technological alternatives and policy proposals for the use of forest residues for energy purposes (40 p.). Brasília.

Brasil. (2010, 3 de agosto). Lei n 12.305, de 2 de agosto de 2010. Política Nacional de Resíduos Sólidos. Diário Oficial [da] República Federativa do Brasil, Brasília. Retrieved in 2019, June 16, from www.planalto.gov.br/ccivil_03/ato2007-2010/2010/lei/12305.htm

Brito, J. O., \& Ceribelli, U. L. (2012). Determination of non-combustible solid contaminants in biomass: evaluation procedure. Piracicaba: Research Group on Bioenergy and Forest Based Bioproducts, USP/ESALQ.

Farage, R. M. P., Rezende, A. A. P., Silva, C. M., Nunes, W. G., Carneiro, A. C. O., Vieira, D. B., \& Rodrigues, C. L. S. (2013). Evaluation of energy use potential of wood residues and derivatives generated in the industrial furniture stave of Ubá - Minas Gerais state. Ciência Florestal, 23(1), 203-212.

Frick, H., Tardif, S., Kandeler, E., Holm, P. E., \& Brandt, K. K. (2019). Assessment of biochar and zerovalent iron for in-situ remediation of chromated copper arsenate contaminated soil. The Science of the Total Environment, 655, 414-422. PMid:30472643. http://dx.doi.org/10.1016/j.scitotenv.2018.11.193.

Jankowsky, I. P., \& Galina, I. C. M. (2013). Drying of wood (36 p.). Piracicaba: ANPM.

Jones, A. S., Marini, J., Solo-Gabriele, H. M., Robey, N. M., \& Townsend, T. G. (2019). Arsenic, copper, and chromium from treated wood products in the U.S. disposal sector. Waste Management, 87, 731-740. PMid:31109576. http://dx.doi.org/10.1016/j.wasman.2019.03.004.

Joshi, O., Grebner, D. L., \& Khanal, P. N. (2015). Status of urban wood-waste and their potential use for sustainable bioenergy use in Mississippi. Resources, Conservation and Recycling, 102, 20-26. http://dx.doi.org/10.1016/j.resconrec.2015.06.010.

Khudyakova, G. I., Danilova, D. A., \& Khasanov, R. R. (2017). The use of urban wood waste as an energy resource. IOP Conference Series: Earth and Environmental Science, 72, 1-8. .

Koyano, S., Ueno, D., Yamamoto, T., \& Kajiwara, N. (2019). Concentrations of POPs based wood preservatives in waste timber from demolished buildings and its recycled products in Japan. Waste Management, 85, 445-451. PMid:30803600. http://dx.doi.org/10.1016/j.wasman.2018.12.039.

Krook, J., Mårtensson, A., \& Eklund, M. (2004). Metal contamination in recovered waste wood used as energy source in Sweden. Resources, Conservation and Recycling, 41(1), 1-14. http://dx.doi.org/10.1016/S0921-3449(03)00100-9.

Liu, Y., Du, J., Dong, Z., Rahman, M. M., Gao, Y., Yan, K., \& Naidu, R. (2019). Bioavailability and risk estimation of heavy metal(loid)s in chromated copper arsenate treated timber after remediation for utilisation as garden materials. Chemosphere, 216, 757-765. PMid:30391898. http://dx.doi.org/10.1016/j.chemosphere.2018.10.141.

Lopes, G. A. (2012). Uso energético de resíduos madeireiros em um pólo de produção de cerâmicas vermelhas do Estado de São Paulo (Tese de doutorado). Escola Superior de Agricultura "Luiz de Queiroz", Universidade de São Paulo, Piracicaba.

Nilsson, K., \& Jermer, J. (1999). Inventory of the use of preservative-treated wood and wood preservatives in Sweden 1900-1997. In Proceedings of the Annual Meeting of the International Research Group on Wood Preservation (IRG/WP 99-50137). Rosenheim, Germany: IRG. 
Nzihou, A., \& Stanmore, B. (2013). The fate of heavy metals during combustion and gasification of contaminated biomass: a brief review. Journal of Hazardous Materials, 256-257, 56-66. PMid:23669791. http://dx.doi.org/10.1016/j.jhazmat.2013.02.050.

Pincelli, A. L. P. S. M. (2011). Characteristics of eucalyptus and pine harvest residues, submitted to thermal treatment, with focus on energetic application (Tese de doutorado). Escola Superior de Agricultura "Luiz de Queiroz", Universidade de São Paulo, Piracicaba.

Remade Scotland. (2004). Wood waste arisings in Scotland: assessment of available data on scottish woodwaste arisings. Glasgow: Drumond House.

Souza, S. S., Santos, P. O., Varejão, M. J. C., \& Nascimento, C. C. (2009). Detection of ash and silica content in lignocellulosic materials. In 61 Annual Meeting of SBPC (pp. 4-5). Retrieved in 2015, May 14, from http://www.sbpcnet.org.br/livro/61 ra/resumos/resumos/5044.htm

U.S. Environmental Protection Agency - USEPA. (2010). 2010 facts and figure fact sheet. Washington: Environmental Protection Agency. Retrieved in 2019, June 16, from http://www.epa.gov/osw/nonhaz/municipal/msw99htm

Vidal, J. M., Evangelista, W. V., Silva, J. C., \& Jankowsky, I. P. (2015). Wood preservation in Brazil: Historical, current scenario and trends. Ciência Florestal, 25(1), 257-271. http://dx.doi.org/10.1590/1980509820152505257.

Zau, M. D. L., Vasconcelos, R. P., Giacon, V. M., \& Lahr, F. A. R. (2014). Chemical, physical and mechanical properties of particleboard produced with Amazon wood waste - Cumaru (Dipteryxodorata) - and castor oil based polyurethane adhesive. Polímeros, 24(6), 726-732. http://dx.doi.org/10.1590/01041428.1594.

Author's contributions: DLF: conceptualization, investigation, data curation, writing - original draft, writing review \& editing, AFDJ: conceptualization, investigation, data curation, writing - original draft, writing - review \& editing, AQL: conceptualization, investigation, data curation, writing - original draft, writing - review\& editing, CRA: methodology, supervision, writing - original draft, resources, Project administration, JOB: methodology, supervision, writing - original draft, resources, project administration, JBGJ: methodology, supervision, writing original draft, resources, project administration. 